This is the final submitted version. Please refer to the published version when citing:

Cohen, E. \& Cohen, S.A. (2015). Beyond Eurocentrism in tourism: A paradigm shift to mobilities. Tourism Recreation Research, 40(2), 157-168.

\title{
Beyond Eurocentrism in Tourism: A Paradigm Shift to Mobilities
}

\begin{abstract}
This article addresses critiques of Eurocentrism in tourism studies, which have called for a "paradigm shift" in response to the rapid rise of tourism from emerging world regions. We clarify the concept of a paradigm shift, and examine arguments for a shift in tourism studies on epistemological, theoretical and empirical levels. We argue for a shift on the theoretical level: the incorporation of tourism studies in the mobilities paradigm. We argue that this paradigm offers a fresh perspective on tourism as enmeshed with other kinds of discretionary mobilities, is free of Eurocentric assumptions, and destabilizes some of the leading concepts on which now problematic binary modernist thinking in tourism studies is based. However, the positivistic, 'etic' character of early studies of the mobilities paradigm hinders its culturally nuanced deployment in emerging world regions, a limitation we seek to remedy by adapting Tim Cresswell's (2010) conceptualization of mobility as comprised of movement, representation and practice. We conclude by a summary of the principal findings of our application of the mobilities paradigm to the comparative study of tourism from the emerging regions.
\end{abstract}

Keywords: Emerging regions, Eurocentrism, paradigm shift, mobilities

\section{Introduction}

In recent years critics have increasingly accused modernist approaches in tourism of 'Eurocentrism', namely of paradigmatic approaches or conceptual and theoretical frameworks based on a Western, i.e. European or Anglosphere perspective. These were alleged to disregard the distinctive traits of tourism from the emerging (often related to as 'nonWestern') regions of the world (e.g. Alneng, 2002, 2009; Hazbun, 2009; Winter, 2009a, 2009b). The purpose of this article is to offer a conceptual framework that helps to overcome the Eurocentric bias in tourism studies, and thereby integrate the study of tourism from the "emerging regions" of the world, which have until recently been treated in modernist tourism studies mainly as destinations of the developed "West", into a paradigm that is unbiased by 
implicit Eurocentric assumptions. We propose a shift away from a prevailing modernist paradigm in tourism studies to the evolving mobilities paradigm (Cresswell, 2006; 2010, 2012; Hannam, Sheller \& Urry, 2006; Sheller \& Urry, 2006; Urry, 2000; 2007). In this article we focus on the epistemological and theoretical issues involved in the shift to the proposed framework; its full empirical application is presented in Cohen and Cohen (2014), which examines domestic, regional and long-haul international tourism from Asia, the Middle East, Latin America, and sub-Saharan Africa..

The mobilities paradigm helps to merge the study of "tourism", conventionally perceived as a distinct, extraordinary phenomenon, involving a round-trip in quest of novelty and change (Cohen, 2004, p. 21-23), with local, national and transnational corporeal mobilities (Hall, 2005a; Williams, 2013), such as pilgrimages, visiting friends and relatives (VFR), second-home commuting, and travel for education or medical treatment, into a bundle of "discretionary mobilities," namely travel undertaken voluntarily with the disposable income left after basic necessities of life have been covered. This merger is of particular importance in the study of tourism from the emerging regions, where voluminous forms of discretionary domestic and regional corporeal mobility have received a relative lack of attention in the literature in comparison to the study of long-haul international 'Western' tourism (Ghimire, 2001; Towner, 1995).

\section{Eurocentrism in tourism studies}

Eurocentrism became a major intellectual and political issue in the last decades of the $20^{\text {th }}$ century (Wallerstein, 1997). Following the publication of Edward Said's Orientalism (1978) and the rise of post-colonial theory (Childs \& Williams, 1997), some basic premises of Western scientific paradigms came under scrutiny. One by one, diverse disciplines were criticized for their Eurocentrism: history (Gran, 1996), geography (McEwan, 1998), sociology 
(McLennon, 2000), linguistics (Gil, 2001), psychology (Kwate, 2001), media studies (Shohat \& Stam, 1994) and even mathematics (Powell \& Frankenstein, 1997).

Tourism studies have been a latecomer to the Eurocentrism debate, which started here only in the last decade. This was prompted by the phenomenal expansion of both domestic and international tourism from the emerging regions of the world, which have until recently been known mainly as destinations for tourists from the affluent West. Eurocentrism was also recognized in the power relations of the tourism academe itself, alongside other skewed variables such as gender, social class and race, wherein the gatekeepers are still mostly "grounded in the Western Anglocentric epistemic research traditions" (Ren, Pritchard \& Morgan, 2010, p. 887). The dominance of research from the "developed world" thus tends to perpetuate "Eurocentric" knowledge production in tourism (Tribe, Xiao \& Chambers, 2012, p.24). Concern over Eurocentrism in tourism studies has not only emanated from the West; Xiao and Smith (2006) note that academic communities in China have tended to uncritically accept the research knowledge generated in the West and have lobbied for China's tourism research to move beyond this inclination.

The alleged differences between the cultural contexts, motivations, perceptions and practices of 'Western' tourists and those from the emerging world regions have provoked a growing critique of an allegedly dominant Eurocentric perspective in the prevailing paradigmatic approaches or theoretical traditions in the study of tourism. That critique has elicited calls for what could be seen as amounting to a "paradigm shift" in the field. But how far-reaching changes in the prevailing approaches these critics demand, and what kind of alternative paradigms they have in view, is not always clear. We shall discuss these questions below, but we have first to clarify our choice of the term "emerging regions."

We have chosen that term as a compromise between the designation of the regions as “non-Western” (e.g. Alneng, 2002; Hazbun, 2009; Winter, 2009a), which represents them as a 
residual category, and older terms, such as "developing countries" or "Third World countries," which seem antiquated in the contemporary globalized world. We have deployed the term to designate the Asian (Arlt, 2006a; Nyíri, 2006; Singh, 2009; Vaporis, 1995; Winter, Teo \& Chang, 2009), Middle Eastern (Al-Hamarneh, 2005; Aziz, 2001; Cai, Scott \& Jafari, 2010), Latin American (Christotffoli, 2007; dos Santos Filho, 2008; Samarchi, 2001) and sub-Saharan African regions (Mkono, 2011, 2013; Rogerson \& Lisu, 2005) of the world. The term is also applicable to some other world regions, such as the Caribbean and Pacific islands, which are not included in our empirical study (Cohen \& Cohen, 2014). However, the use of the term "emerging regions" should not be understood that we perceived them as homogeneous entities; we recognize differences between, and within, the nation-states in each region, as well as similarities between them and Western ones, effected by the process of globalization. Our use of the term "Western" has similar limitations, albeit not constituting a residual category, and is used here to designate the European and Anglosphere world regions.

\section{Paradigm Shift}

"Paradigms" were first defined as "accepted examples of actual scientific practice...from which spring particular coherent traditions in scientific research" (Kuhn, 1970, p. 10). A more recent definition is offered by Griffin (2014), who defines a "paradigm" as "a basic set of beliefs that guide both the conduct and scope of inquiry". Tribe (2006, p. 366) explicates that "[p]aradigms set the rules and define the boundaries of the acceptable in knowledge creation and represent an important power dimension acting on research," owing to the entrenched hegemony or monopole on scientific "truth" held by leading scientists, who block new ways of creating radically novel knowledge in the field.

The terms "paradigm," and hence "paradigm shift", have been deployed at different levels of methodological depth; we distinguish three levels: 
One, a shift on the fundamental epistemological (how the world is made intelligible or knowledge is constructed [Goodson \& Phillimore, 2004]) level. Peter Winch's (1990 [1958]) argument against Pareto is an enlightening example. Winch (ibid, p. 102) argues that Pareto elevated "scientific intelligibility...as the norm for intelligibility in general; he is claiming that science possesses the key to [all] reality". Against this paradigm of knowledge, which in contemporary philosophy would be called "scientism," Winch poses what could be seen as an alternative, pluralistic, Wittgensteinian, paradigm. He claims that "philosophy is concerned with elucidating and comparing the ways in which the world is made intelligible in different intellectual disciplines, and how this leads to the elucidation and comparison of different forms of life" (ibid, p. 102). He concludes that "intelligibility takes many and varied forms;" hence "reality has no [single] key" (ibid, p. 102). It follows that "criteria of logic...rise out of, and are only intelligible in the context of...modes of social life" (ibid, p. 100). Implicit in Winch's pluralistic position is that the internal logics of different forms of life are incommensurable, and hence preclude full mutual understanding.

Two, a shift in the basic assumptions underlying the scientific activity in a given field, but not in its epistemological prerequisites; this involves a shift in theoretical perspective on the field and the substitution of one theoretical approach by another. That concept of a paradigm shift, close to Kuhn's (1970) original formulation, has been quite commonly applied to changes in theoretical perspective in various realms of the social sciences. A purview of the literature rends some typical examples, such as: the shift in learning psychology from objectivism to constructivism (Jonassen, 1991), from goods-centered, transaction-based models to a relationship orientation, network approach or service dominant logic in marketing studies (Li and Petrick, 2008); or from automobility planning to accessibility planning in transportation science (i.e. from focus on travel to focus on people) (Cervero, 1996). 
Three, the concept of paradigm shift has also been more loosely, and inaccurately, deployed as a metaphor for some far-reaching empirical permutations in a field, which do not necessarily entail a major theoretical transformation. Examples of such usage in the social science literature come from various fields, such as the shift from statism to federalism in post-WWII political science (Elazar, 1995), and a shift from professionalism to a market ethic noted in medical health care research (Pellegrino, 1999). Such empirical shifts, unaccompanied by theoretical transformations cannot, in our view, be considered "paradigm shifts;" but, as we shall see below, new kinds of empirical data, which do not fit accepted theoretical frameworks, can become a trigger of such a shift.

\section{Tourism from the Emerging Regions and Paradigm Shift}

With the remarkable rise of Asian tourism, first primarily from Japan and Korea (Prideaux, 1997; Vaporis, 1995), and more recently from China (Arlt, 2006a; Li et al., 2010), a concomitant, but less spectacular growth in tourism from the Middle East (Cai et al., 2010; Prayag \& Hosany, 2014 on United Arab Emirates) and Latin America (Christoffoli, 2007 on Brazil; Sammarchi, 2001 on Argentina), and an incipient tourism from Sub-Saharan Africa (Mkono, 2011, 2013 on Zimbabwe; Rogerson, 2004; Rogerson \& Rogerson 2011 on South Africa), several authors argued that prevailing contemporary theories in tourism studies are not applicable to tourists from these emerging regions (e.g. Alneng, 2002, 2009; Hazbun, 2009; Winter, 2009a; 2009b), and at least implicitly called for a paradigm shift in the field. That call, however, has been voiced at different levels of methodological depth, and hence there are significant differences in the radicalism of the suggested "paradigm shift".

One, a demand for the most radical shift, an epistemological one, is based on Syed Faris Alatas' programmatic call for "alternative discourses" in the social sciences, whose task would be the "liberation [of non-Western social sciences] from the problem of the irrelevance 
of the Euro-American social sciences"; Alatas stressed "the need to create the conditions under which alternative social sciences in non-Western societies may emerge" (2006, p. 1718). Mignolo (2014) has recently provided support for a radical paradigm shift in the social sciences.

Winter (2009a), discussing the need for critical tourism scholarship within the Asian region quotes, and apparently endorses, Alatas" definition of "alternative discourses" as a basis for a radical paradigm shift in Asian tourism studies:

"Being alternative means a turn in philosophies, epistemologies, histories, and the arts other than those of the Western tradition. These are all to be considered as potential sources of social science theories and concepts, which would decrease [Asian] academic dependence on the world social science powers" (Alatas, 2006, p. 82, quoted in Winter, 2009, p. 323).

In Winchian (1990 [1958]) terms this seems to be a call for a different, particularly Asian, logic or intelligibility for social science discourse, including that of tourism, which will liberate Asian social science of allegedly post-colonial Western paradigms, purportedly dominating or monopolizing what counts as knowledge in the social sciences. How such a liberation from Eurocentrism will work out concretely in the domain of tourism, indeed, whether "tourism" will figure at all in an Asian social science vocabulary, are open questions.

Two, suggestions for a paradigm shift on the theoretical level, on which Kuhn's (1970) original conception was formulated, have been offered by several scholars in tourism studies. A call for such a shift is implicit in a short paper by the historian of tourism John Towner (1995, p. 340) in which he argued that "[ $t]$ he conventional image is a colonial view of tourism history, whereby an activity defined by and researched in western cultures is seen to have been brought over time to new peoples and societies." Towner (ibid, p. 340) points out that "[s]uch a view... underplays the informal, the routine, the 'ordinary', more localized, tourism practices as they have varied between and within countries and cultures". He concludes that "[s]o far, all we have studied is a western model of tourism evolution, not how 
it has varied in different cultures and different times" (ibid, p. 340). Towner thus calls expressly for a shift from a paradigmatic assumption of a single Western origin of tourism, which in turn has been disseminated throughout the world, to an assumption of a plurality of independent originations in diverse localities and times. Hazbun (2009, p. 205) similarly argued that the view that tourism developed in England and from there diffused over the world "ignores other possible points of origin".

But a more comprehensive demand for a "paradigm shift" is implied in the criticism launched by representatives of post-colonial theory against a Eurocentric bias in the modernist approach to the study of tourism. Alneng (2002, p. 124) offered a radical criticism of the paradigm allegedly implicit in much tourism research, arguing that "[i]f the West is appointed the homeland of both modernity and tourism, this is...a view based on an autocentric modernity expressing self-proclaimed universal certainty." Alneng (ibid, p. 130) points out that "...theories developed in the modernist enclave of Tourist-as-Westerner might not be as universal as they have been posed to be".

From the writings of post-colonial critics it can be inferred that modernist studies of tourism are based on a cluster of unacknowledged Eurocentric paradigmatic assumptions: First, tourism is a modern Western phenomenon. It has been born in the West and spread from there to the rest of the world (e.g. Urbain in Doquet \& Evrard, 2008, quoted in Hazbun, 2009, p. 203). Second, the dominant geographic pattern of international tourism is from developed Western or Westernized countries into the undeveloped "pleasure periphery" (Turner \& Ash, 1975); that pattern was represented either as a uni-directional "North-to-South" or "West-toEast" flow (Winter, 2009, p. 23). Third, Westerners are the international tourists and the people of the destinations are the hosts or tourees (Lengkeek \& Platenkamp, 2008; Mkono, 2011; Nyíri, 2006). Fourth, tourists travel in quest of difference, authenticity and/or the “exotic" Other (Said, 1978; Hazbun, 2009). 
One of the consequences of these assumptions was a bias in tourism research towards long-haul international Western tourism, and a relative lack of attention to domestic and regional tourisms (Ghimire, 2001), as well as an absence of conceptual and theoretical readiness to deal with the rising wave of tourists from Asia and the other emerging regions in the last two decades. Thus Alneng, writing in the early 2000s, argued that this paradigmatic view of tourism led to a "relative indifference towards, and sometimes complete denial of, non-Western tourism" (2002, p. 137), a state of affairs which a decade later has been at least partly rectified. But neither Alneng, Winter nor any other critic of Eurocentrism in tourism studies have yet proposed an alternative paradigm on a theoretical level, which could account for the allegedly different dynamics of tourism from the emerging regions.

\section{Paradigm Shift in Tourism Studies}

Significant empirical differences between the aspired tourist experiences, perceptions and practices of Western tourists and those from the emerging regions have been increasingly documented by contemporary tourism research (e.g. Chang, Kivela \& Mak, 2011; Chen, Bao \& Huang, 2013; Li et al., 2011; Xu, Cui, Ballantyne \& Packer, 2013). But modernist researchers failed to develop new theoretical frameworks which would account for these differences. Thus, a cornerstone assumption of MacCannell's (1976) influential modernist theoretical approach was that alienated moderns are in quest of (objective) "authenticity" (MacCannell, 1976; Cohen, 1979, 2007; Wang, 1999). But observations that tourists from the emerging regions, particularly Asians and Africans, are not looking for authenticity (Mkono, 2013; Oakes, 2006; Shepherd, 2009) as modern Westerners allegedly did, have not been incorporated into that - or any other modernist - theoretical approach. The negligence of this and other differences served critics as the basis for the claim that current theories are inapplicable to tourism from the emerging regions. Thus Arlt (2006b, n.p.) noted that 
Mainland Chinese tourist behavior "is not based on western individual values like selfactualization, recreation as non-activity, individually experienced authenticity etc." Arlt argued that this "puts into question many of the - normally implicit - assumptions of 'classical' tourism behaviour theories."

Implicit in the foregoing criticisms of modernist approaches to the study of tourism is a call for a paradigm shift in the field, whether on the epistemological or the theoretical level. We believe, however, that a contrarian epistemological strategy, positing some "Asian" paradigm against a "Western" one, would be counter-productive, and split the field into two incommensurable "forms of life" (Winch, 1990 [1958], p. 102), by in fact ironically reproducing the very Orientalist attitude which it seems to be contesting. We therefore favor a paradigm shift on the theoretical level, since most critiques of Eurocentrism in tourism studies were conducted on this level, their major target being the Eurocentrism of modernist theories of tourism. However, the argument for a paradigm shift on this level has to take account of the broad ongoing process of meta-theoretical re-orientation in contemporary thought, which is currently engendering paradigm shifts in several social sciences. As Cohen and Cohen (2012, p.2180) recently pointed out, that re-orientation consists of a shift:

"from a synchronic to a diachronic perspective, involving a change of emphasis from permanence to flux, from being to doing, from structure to agency, from sedimented social patterns to the process of their emergence and from a focus on the more stable fixtures of social life to the mobilities linking them".

Among the various theoretical approaches incorporating that re-orientation, we have chosen to focus on the evolving mobilities paradigm, since it is not narrowly focused on "tourism" as conventionally defined, embraces a wide range of scales of movement, and is globally applicable, but without a Eurocentric bias. 


\section{The Mobilities Paradigm as a Non-Eurocentric Approach to the Global Study of Tourism}

The ongoing development of the mobilities paradigm (Adey, 2009; Cresswell, 2006, 2010, 2012; Glick Schiller \& Salazar, 2013; Hannam et al., 2006; Sheller \& Urry, 2006; Urry, 2000, 2007) straddles the boundary between modern and postmodern theorizing. While it shares with modernist theories basic epistemological, and even positivist, assumptions, as we discuss further below, it destabilizes some of the leading concepts on which modernist thinking and research in the study of tourism has been based, such as binary distinctions between home/away, work/leisure, host/guest, domestic/international and everyday life and extraordinary holidays (Cohen \& Cohen, 2012; Franklin \& Crang, 2001).

Implicit in earlier works of anthropologists, such as Clifford (1997) on traveling cultures and Bruner $(1995 ; 2005)$ on the global/local interface of travelers and visited cultures, the mobilities paradigm was developed programmatically in sociology by Urry (2000). It soon became viewed as a post-disciplinary approach by tourism scholars, who saw its potential for enhancing theorization in tourism studies by locating tourism within the wider spectrum of mobilities (Coles, Hall \& Duval, 2006), and has also resonated in other areas of the social sciences, such as geography (e.g. Adey, 2009; Cresswell, 2006, 2012) and migration studies (e.g. Glick Schiller \& Salazar, 2013). Mobilities theorists themselves are seemingly not yet in agreement on whether a mobilities perspective offers a full-fledged paradigm, and hence refer to it variously as a "paradigm," "turn" or "approach," often using these words interchangeably. We believe, however, that it constitutes a nascent paradigm, because it involves a major theoretical transformation in the basic assumptions underlying social scientific activity. Mobilities theorists claim that social science had been largely sedentarist, wherein boundedness was normalized and movement was trivialized or ignored (Sheller \& Urry, 2006). In contrast, the mobilities approach introduces an alternative 
theoretical perspective that prioritizes the fluidity of movements over the stasis of structure in contemporary society (Urry 2000). It thus has the qualities of Kuhn's (1970) original formulation of a paradigm shift on the theoretical level.

The mobilities paradigm has introduced a radical shift in the sociological perception of "societies". Rather than as a collection of bounded entities, as they were conceived in modernist "methodological nationalism" (Wimmer \& Glick Schiller, 2003), societies came to be perceived as merged in an encompassing "boundless network of diverse flows [of people, goods, capital, information and knowledge], interconnected by nodes" or moorings (Hannam et al., 2006, p. 5). This "networked" understanding of societies has drawn criticism that the mobilities paradigm has done little more than "lump" together adjacent phenomena (Aramberri, 2010), mirroring the wider scientific debate on "lumpers" and "splitters" (Pearce, 2011). Lumping approaches attempt to create patterns from diversity whereas splitting approaches put emphasis on difference, context and complexity (ibid). While it is true that the mobilities paradigm views forms of mobility as embroiled with one another (Coles et al., 2006), it is precisely this interconnected perspective that allows for a deeper understanding of how factors, such as context and power differentials, work to co-constitute a range of mobility practices that bleed into each other. Its networked approach thus teases out complexities that are lost when looking at phenomena in isolation and should consequently not be categorized as lumping.

Recent work has nonetheless also criticized the early mobilities studies of underemphasizing the significance of various obstacles to mobility and instead overly elevating the fluidity and flows of movement (Glick Schiller \& Salazar, 2013). Although the proponents of the mobilities paradigm have now started to study such topics as how waiting and stillness are "incorporated into the practices of moving" (Cresswell, 2012, p. 648), mobilities scholars have only began to pay more systematic attention to the obstacles to and 
governance of mobility (Baerenholdt, 2013; Coles \& Hall, 2011; Cohen, 2012; see Richardson, 2013 for a special issue on borders and mobilities). This is illustrative of the growing emphasis in mobilities studies on the significance of power differentials for one's ability to move (Cresswell, 2010, Glick Schiller and Salazar 2013). While the mobilities paradigm is at least partly "a result of a dissatisfaction with the valorization of forms of stillness - rooted and the sedentary" (Cresswell, 2012, p. 648) that has characterized earlier social science approaches, which tended to fix people and practices in bounded territories, mobilities theorists have yet to propose a theoretical framework accounting for the interconnectedness of stasis and movement in various kinds of mobilities. Glick, Schiller and Salazar's (2013) recent introduction into mobilities studies of the concept of "regimes of mobility" which act to "normalize the movements of some travelers while criminalizing and entrapping the ventures of others" (ibid, p. 189) will help to develop an integrated approach to such issues.

The mobilities paradigm offers a fresh perspective on tourism as enmeshed with other kinds of corporeal mobilities (Coles et al., 2006), rather than as a distinct extraordinary practice, disentangled from everyday life (Duncan, Scott \& Baum, 2013; Franklin \& Crang, 2001; Hannam et al., 2006). Tourism is conceived as constituting a vaguely distinguishable subset in a network of diverse flows of people, goods, capital, and information (Hannam et al., 2006), entangled in practice with other forms of discretionary mobility, such as pilgrimages, VFR (Barnett et al., 2010; Uriely, 2010; Uriely \& Shani, 2012), second-home commuting (Hall \& Müller, 2004), “old home” visits (Duval, 2003; King \& Christou, 2011), as well as with travel for education, medical treatment, business, work and transnational migration (Schiller, Basch \& Blanc, 1995).

Several works suggested that the mobilities paradigm offers an approach that takes account of the increasingly blurred boundaries between tourism and other categories of local, 
national and global corporeal movements, ranging from short-term to permanent, and from voluntary to coerced (Cohen, Duncan \& Thulemark, 2014; Duncan, 2012; Glick Schiller \& Salazar, 2013; Hall, 2005a, 2005b; Mavrič \& Urry, 2009; Sheller \& Urry, 2004). Tourism is thus denied the status of a privileged form of movement and seen as enmeshed spatially, temporally and socially (Williams, 2013) with other kinds of mobilities, including everyday mundane ones (Edensor, 2007), virtual and imaginative ones (Urry, 2002), and with the movements of objects, capital and information (Hannam et al., 2006). Viewed as an everyday activity (Edensor, 2007; Larsen, 2008), tourism is uncoupled from the quest for the exotic Other, the quintessential motive of modernist Western tourists (MacCannell, 1976). A mobilities approach has been deployed in some empirical studies of tourism (for a review see Hannam, Butler \& Paris, 2014), such as by Larsen (2001) on experiences of motorized mobility, Duval (2003) on the return mobilities of a Caribbean diaspora, Lean (2012) on a mobilities perspective towards "transformative travel," Duncan et al. (2013) on the mobilities of tourism and hospitality workers and by Edensor (2007) on mundane tourist performances.

Initiated by mainly Western researchers as a conceptual framework to deal with the unprecedented fluidity or "liquidity" (Bauman, 2000) of late modernity, the mobilities paradigm is marked by some implicit neoliberal, individualistic tendencies, and arguably has a path dependency since it evolved in reaction to Western modernist thought. It is largely free, however, of Eurocentric assumptions: in the context of tourism, it does not distinguish between a center and periphery of tourist activity; it does not assume a single point of dissemination of tourism; and it does not prioritize a particular kind of motivation for tourism.

A distinguishing quality of the mobilities paradigm, which makes it particularly convenient for the study of tourism from the emerging regions, is that its scope extends to corporeal movement on all scales (Cresswell, 2006), from walking (e.g. Hall and Smith, 2013) to space travel, and hence can take account of the kind of low-scale, localized, 
everyday forms of tourism, which Towner (1995, p. 339) and Edensor (2007) drew attention to, but were generally disregarded by modernist theoreticians of tourism. Thus, the mobilities approach helps to foreground the voluminous domestic and regional tourism flows within the emerging regions for purposes such as VFR, pilgrimage and entertainment, which were often neglected by researchers due to their limited geographical scale (Ghimire, 2001).

Several mobilities theorists, migration scholars and anthropologists have begun to analyze mobilities within the emerging regions: for instance, Kalir (2013) on the flow of migrant workers from China to Israel; Pelican (2013) on perspectives on international migration amongst youths in Cameroon; Salazar (2013) on imaginaries and the value of immobility in Chile; and Hannam and Butler (2012) on tourism mobilities in Africa. However, the potential of the mobilities approach as a general paradigm at the theoretical level for the study of both Western tourism and tourism from the emerging regions has not yet been systematically explored. Toward that goal, we have recently undertaken a comparative study of tourism mobilities from four emerging world regions at the domestic, regional and long-haul international levels (Cohen \& Cohen 2014).

However, since the mobilities paradigm, as initially conceived on the macro-scale by Urry (2000), had a marked positivistic or "etic" character, it avoided, rather than resolved, some of the dominant issues regarding the alleged differences between Western tourists and those from the emerging world regions, like for example in their culturally-conditioned motivations for travel. To enable an explicit discussion of such culturally sensitive issues, we take recourse to Cresswell's (2010) classification of the basic components of the process of human mobility. Cresswell distinguishes and defines three major aspects of corporeal mobility: movement, representation and practice. Cresswell (ibid, p. 19-20) defines physical movement as "getting from one place to another" or the "raw material for the production of mobility", representation as how movement is coded or figured to "give [it] shared meaning", 
and practice as "the experienced and embodied [enactment] of movement." Cresswell (ibid, p. 19) emphasizes that the three aspects are "bound up with one another;" hence their "disentanglement is entirely analytical and its purpose is to aid theory construction", but he discusses each aspect separately, without engaging in the clarification of their interrelationships.

Cresswell (2010) further breaks mobility down into a set of six elements, namely motive force, speed, rhythm, routing, experience and friction, but does not expressly specify how these aspects relate to the three entangled components of mobility. Finally, Cresswell (ibid, p. 26-27) develops the highly useful concepts of "constellations of mobility" and "(social) hierarchies of mobility," and deploys these concepts to a politico-historical analysis of the constellations (or assemblages) of mobility in the Western world. We have attempted to deploy these concepts to a comparative study of constellations of mobilities in the emerging regions of the world.

For our purposes, we have slightly adapted Cresswell's concepts: first, we conceive of "movement" as a purely spatial concept, positivistic (Cresswell, 2010) and "etic" (i.e. as defined and measured by an external scientific observer). Second, in contrast, we see "representation" as an "emic" (i.e. culturally grounded) perception and interpretation of movement (e.g. movement represented as adventure, tedium, education, freedom and so on). Third we conceive of "practices" as performative acts (Austin, 1978), having both an "etic" character as movement, and an "emic" character as representation: the meaning of a performance of some embodied practice can be perceived in different, and often contrasting, ways (e.g. as "work," "play," "simulation" or "acting"). Some of Cresswell's (2010) elements of mobility detail primarily "etic" aspects of "movement" (e.g. speed, rhythm, routing and friction), while others detail primarily "emic" aspects of "representation" (e.g. motive force and experience). All of them are aspects of "practices". 
To sum up: we propose to conceive of corporeal mobilities as a complex of movements (etic), performed by configurations of activating, regulating and resisting practices (etic/emic), endowed with (contested) meanings, which tend to coagulate into (conflicting) representations (emic).

The application of the this modified mobilities paradigm to tourism from the emerging regions (Cohen \& Cohen 2014), yielded some significant insights, such as: one, the adaptation of distinctive indigenous emic notions for discretionary travel to the globalized Western concept of tourism; two, the evolution of new 'mobility constellations' accompanying technological innovations in travel and the increasing elimination of impediments on movement; three, the broadening of the 'kinetic hierarchy' with the adoption of new means of movement and the emergence of middle classes in the process of modernization, which however, still leaves the lower classes mostly immobile; four, the absorption of pilgrimage into hybridized patterns of contemporary discretionary travel; five, the emergence and spread of discretionary travel on the domestic and regional scales in the emerging regions, which is increasingly overshadowing Western inbound tourism; and six, the differences between the regions in the extent and modes of participation in international long-haul discretionary travel.

\section{Conclusions}

This article has responded to calls for a paradigm shift in tourism studies in light of the criticism that modernist Eurocentric theories are not applicable to rapidly expanding tourism flows from the emerging regions of the world (Alneng, 2002; Hazbun, 2009; Winter, 2009a). We have done so by clarifying the concept of a "paradigm shift" on three levels and examined arguments for a paradigm shift in the study of tourism on each of these. We have prioritized the theoretical level, and consequently advocated a re-orientation of tourism studies to the evolving mobilities paradigm. We sought to demonstrate how, by adapting Cresswell's (2010) 
conceptualization of mobility as comprised of movement, representation, and practice, an unbiased, culturally nuanced deployment of the mobilities paradigm to the context of tourism from the emerging world regions is made feasible.

We have demonstrated that the mobilities paradigm moves beyond Eurocentrism in tourism studies by not distinguishing between a center and periphery of tourist activity, not assuming a singular point of dissemination of tourism, and not prioritizing particular motivations for tourism. It thus decenters modernist tourism discourse that positioned "tourism" as a modern Western phenomena, whereby the emphasis was placed all too often on international North-to-South or West-to-East tourism. The mobilities paradigm offers a powerful corrective to Eurocentrism in the tourism literature, and gives due focus to the previously neglected voluminous domestic and regional tourism practices, and their association with other forms of discretionary corporeal movement, such as pilgrimages, VFR and entertainment in the emerging regions of the world.

Our treatment of this issue was however limited in important ways: first, we did not undertake a systematic analysis of the sources of power differentials in access to discretionary mobilities in the emerging regions, which is an important area of concern and open to further research. Second, we have not accounted for the different dynamics of discretionary mobilities in countries at various levels of development in each of the emerging regions. Our work is thus an introduction for future, more nuanced comparative studies. Third, we dealt only with Eurocentrism in modernist tourism theories, rather than in research methods. The applicability of current scientific methods in tourism studies to the emerging regions has to be separately tested (see for instance Yang, Ryan \& Zhang, 2012).

\section{References}

Adey, P. (2009). Mobility. London: Routledge. 
Alatas, S.F. (2006). Alternative discourses in Asian social science: responses to Eurocentrism. New Delhi: Sage Publications India.

Al-Hamarneh, A. (2005). New tourism trends in the Arab world. Islamic Tourism, 16, 50-54.

Alneng, V. (2002). The modern does not care for natives: travel ethnography and the conventions of form. Tourist Studies, 2(2), 119-142.

Alneng, V. (2009). Zen and the art of tourism maintenance: a meditation on so-called prototourism in Vietnam. In Sh. Singh (Ed.), Domestic tourism in Asia (pp. 31-49). London: Earthscan.

Aramberri, J. (2010). The real scissors crisis in tourism research. In D.G. Pearce and R. Butler (eds) Tourism Research: A 20:20 Vision (pp. 15-27). Oxford: Goodfellow Publishers.

Arlt, G.W. (2006a). China's outbound tourism. Oxford: Routledge.

Arlt, W.G. (2006b). Chinese tourists behaviour in "Elsewhereland." Paper, Leeds

Metropolitan University, Tourism in Asia, 10-12 June 2006 (un-paginated).

Aziz, H. (2001). The journey: an overview of tourism and travel in the Arab/Islamic context. In D. Harrison (Ed.) Tourism and the less developed world: Issues and case studies (151160). Wallingford, Oxon: CAB International.

Baerenholdt, J.O. (2013). Governmobility: The powers of mobility. Mobilities, 8(1), 20-34.

Barnett, E.D., MacPherson, D.W., Stauffer, W.M., Loutan,, L., Hatz, C.F., Matteelli, A. \& R.H. Behrens (2010). The visiting friends or relatives traveler in the $21^{\text {st }}$ century: Time for a new definition. Journal of Travel Medicine, 17(3), 163-170.

Bruner, E. (1995). The ethnographer/tourist in Indonesia. In M-.F. Lanfant, J. Allcock \& E. Bruner (Eds) International Tourism: Identity and Change (pp. 224-41). London: Sage.

Bruner E.M. (2005). Culture on Tour: Ethnographies of Travel. Chicago: University of Chicago Press.

Cai, L.A., Scott, N. \& Jafari, J. (2010). Tourism in the Muslim world. Bingley, U.K.: Emerald.

Cervero, R. (1996). Paradigm shift: from automobility to accessibility planning. Working Paper 67, University of California, Berkeley, Institute of Urban and Regional Development.

Chang, R.C.Y., Kivela J. \& Mak, A.H.N. (2011). Attributes that influence the evaluation of travel dining experience: when east meets west. Tourism Management, 32(2), 307-316.

Chen, G., Bao, J. \& Huang, S. (2013). Segmenting Chinese backpackers by travel motivations. International Journal of Tourism Research, DOI: 10.1002/jtr.1928.

Childs, P. and R.J.P. Williams (1997). An introduction to post-colonial theory. New York: Prentice-Hall. 
Cohen, E. (1979). A phenomenology of tourist experiences. Sociology 13(2): 179-201.

Cohen E. (2004) Contemporary tourism: Diversity and change. Amsterdam: Elsevier.

Cohen, E. (2007). "Authenticity" in tourism studies: après la lutte. Tourism Recreation Research, 32(2), 75-82.

Cohen, E. (2012). Globalization, global crises and tourism. Tourism Recreation Research, 37(2), 103-111.

Cohen, E. \& Cohen, S.A. (2014). A mobilities approach to tourism from emerging world regions. Current Issues in Tourism. http://dx.doi.org/10.1080/13683500.2014.898617

Cohen, E. \& Cohen, S.A. (2012) Current sociological theories and issues in tourism. Annals of Tourism Research 39(4), 2177-2202.

Cohen, S.A., Duncan, T. \& Thulemark, M. (2014). Lifestyle mobilities: The crossroads of travel, leisure and migration. Mobilities, DOI: 10.1080/17450101.2013.826481.

Coles, T. \& Hall, C.M. (2011). Rights and regulation of travel and tourism mobility. Journal of Policy Research in Tourism, Leisure \& Events, 3(3), 209-223.

Coles, T., Hall, C.M. \& Duval, D.T. (2006). Tourism and post-disciplinary enquiry. Current Issues in Tourism, 9(4-5), 293-319.

Clifford, J. (1997). Routes: Travel and Translation in the Late Twentieth Century, Cambridge: Harvard University Press.

Cresswell, T. (2006). On the move: mobility in the modern Western world. New York: Routledge.

Cresswell, T. (2010). Towards a Politics of Mobility. Environment and Planning D:

Society and Space, 28, 17-31.

Cresswell, T. (2012). Mobilities II: still. Progress in Human Geography, 36(5), 645-653.

Christoffoli, A.R. (2007). Turismo e religiosidade no Brasil, Ph.D. Thesis, Centro de Educação em Balneário Camboriú, Universidade do Vale do Italaí-Univali.

Doquet, A \& Evrard, O. (2008). An interview with Jean Didier Urbain: tourism beyond the grave: a semiology of culture. Tourist Studies, 8(2), 175-182.

dos Santos Filho, J. (2008). Política nacional de turismo: descaso e desrespeito para com o povo brasileiro. Revista espaço academic, 86.

Duncan, T., Scott, D.G.S. \& Baum, T. (2013). The mobilities of hospitality work: an exploration of issues and debates. Annals of Tourism Research, 41(1), 1-19.

Duncan, T. (2012). The "mobilities turn" and the geography of tourism. In J. Wilson (Ed.), The Routledge handbook of tourism geographies (pp. 113-119). London: Routledge. 
Duval, D. T. (2003). When hosts become guests: Return visits and diasporic identities in a Commonwealth Eastern Caribbean community. Current Issues in Tourism, 6(4), 267-308.

Edensor, T (2007). Mundane mobilities, performances and spaces of tourism, Social \& Cultural Geography, 8(2), 199-215.

Elazar, D.J. (1996). From statism to federalism - a paradigm shift. International Political Science Review, 17(4), 417-428.

Franklin, A. \& Crang, M. (2001). The trouble with tourism and travel theory? Tourist Studies, $1(1), 5-22$.

Ghimire, K.B. (2001). The growth of national and regional tourism in developing countries: An overview. In K.B. Ghimire (Ed.) The native tourist: Tourism development within developing countries (pp. 1-29) London: Earthscan.

Gil, D. (2001). Escaping Eurocentrism: fieldwork as a process of unlearning. In P. Newman and M. Ratcliff eds. Linguistic fieldwork. Cambridge: Cambridge University Press.

Glick Schiller, N. \& Salazar, N.B. (2013). Regimes of Mobility across the Globe. Journal of Ethnic and Migration Studies 39(2): 183-200.

Goodson, L. \& Phillimore, J. (2004). The inquiry paradigm in qualitative tourism research. In J. Phillimore \& L. Goodson (Eds.), Qualitative research in tourism: ontologies, epistemologies and methodologies (pp. 30-45). London: Routledge.

Gran, P. (1996). Beyond Eurocentrism: a new view of modern world history. Syracuse: Syracuse University Press.

Griffin, T. (2014). A paradigmatic discussion for the study of immigrant hosts. Current Issues in Tourism, DOI:10.1080/13683500.2012.755157.

Hall, C.M. (2005a). Reconsidering the geography of tourism and contemporary mobility. Geographical Research 43(2), 125-139.

Hall, C.M. (2005b). Tourism: Rethinking the social science of mobility. Essex: Pearson Prentice Hall.

Hall, C.M. \& Müller, D.K. (2004). Tourism, mobility and second homes. Bristol: Channel View Publications.

Hall, T. \& Smith, R.J. (2013). Stop and go: a field study of pedestrian practice, immobility and urban outreach work. Mobilities, 8(2), 272-292.

Hannam, K. (2009). The end of tourism? Nomadology and the mobilities paradigm. In J. Tribe (Ed.), Philosophical Issues in Tourism (pp. 101-113). Bristol: Channel View Publications.

Hannam, K. \& Butler, G. (2012). Engaging the new mobilities paradigm in contemporary African tourism research. Africa Insight, 42(2), 127-135. 
Hannam, K. Butler, G. \& Paris, C.M. (2014). Developments and key issues in tourism mobilities. Annals of Tourism Research, 44, 171-185.

Hannam, K., Sheller, M. \& Urry, J. (2006). Editorial: Mobilities, immobilities and moorings. Mobilities, 1(1), 1-22.

Hazbun, W. (2009). Modernity at the beach: a postcolonial reading from southern shores. Tourist Studies, 9(3), 203-222.

Jonassen, D.H. (1991). Objectivism versus constructivism: do we need a new philosophical paradigm? Educational Technology, 39(3), 5-14.

Kalir, B. (2013). Moving subjects, stagnant paradigms: Can the "mobilities paradigm" transcend methodological nationalism? Journal of Ethnic and Migration Studies, 39(2), 311327.

King, R. \& Christou, A. (2011). Of counter-diaspora and reverse transnationalism: Return mobilities to and from the ancestral homeland. Mobilities, 6(4), 451-466.

Kuhn, T.S. (1970). The structure of scientific revolutions. Chicago: Chicago University Press.

Kwate, N.O.A. ( 2001). Intelligence or misorientation? Eurocentrism in the WISC-III. Journal of Black Psychology, 27(2), 211-218.

Larsen, J. (2001). Tourism mobilities and the travel glance: experiences of being on the move. Scandinavian Journal of Hospitality and Tourism, 1(2), 80-98.

Larsen, J. (2008). De-exoticizing tourist travel: Everyday lives and sociality on the move. Leisure Studies, 27(1), 21-34.

Lean, G.L. (2012). Transformative travel: a mobilities perspective. Tourist Studies, 12(2), 151-172.

Lengkeek, J. \& Platenkamp, V. (2008). The International Classroom of Tourism Studies. Background paper, International Conference "Ever the twain shall meet - relating international and domestic tourism" of Research Committee RC50 International Tourism, International Sociological Association, Jaipur, Rajasthan, India, November 24-26, 2008.

Li, X., Harrill, R., Uysal, M., Burnett, T. \& Zhan, X. (2010). Estimating the Size of the Chinese Outbound Travel Market: A Demand-Side Approach. Tourism Management, $31,250-59$.

Li, X., Lai, C., Harill, R., Kline, S. \& Wang, L. (2011). When east meets west: An exploratory study on Chinese outbound tourists' travel expectations. Tourism Management, 32(4), 741-749.

Li, X. \& Petrick, J.F. (2008). Tourism marketing in an era of paradigm shift. Journal of Travel Research, 46, 235-244. 
MacCannell, D. (1976). The tourist: a new theory of the leisure class. New York: Schocken Books.

Mavrič, M. \& J. Urry (2009). Tourism studies and the New Mobilities Paradigm (NMP). In T. Jamal \& M. Robinson (Eds.), The Sage Handbook of Tourism Studies (pp. 645-657). London: Sage.

McEwan, C. (1998). Cutting power lines within the palace? Countering paternity and Eurocentrism in the "geographical tradition". Transactions of the Institute of British Geographers 23(3), 371-384.

McLennon, G. (2000). Sociology's Eurocentrism and the "rise of the West". European Journal of Social Theory 3(3), 275-291.

Mignolo, W.D. (2014). Spirit out of bounds returns to the East: the closing of the social sciences and the opening of independent thoughts. Current Sociology, 62, 584-602.

Mkono, M. (2011). African as tourist. Tourism Analysis, 16, 709-713.

Mkono, M. (2013). African and Western tourists: object authenticity quest? Annals of Tourism Research 41, 195-214.

Nyíri, P. 2006. Scenic spots; Chinese tourism, the state and cultural authority. Seattle: University of Washington Press.

Oakes, T. (2006). Get real! On being yourself and being a tourist. In C. Minca \& T.

Oakes (Eds.), Travels in paradox: remapping tourism (pp. 229-250). Lanham:

Rowman \& Littlefield.Pearce, P.L. (2011). Tourist Behaviour and the Contemporary World. Bristol: Channel View Publications.

Pelican, M. (2013). International migration: Virtue or vice? Perspectives from Cameroon. Journal of Ethnic and Migration Studies, 39(2), 237-258.

Pellegrino, E.D. (1999). The commodification of medical and health care: the moral consequences of a paradigm shift from a professional to a market ethic. Journal of Medical Philosophy, 24(3), 243-266.

Powell, A.P. and M. Frankenstein (1997). Ethnomathematics - challenging Eurocentrism in mathematics education. Albany NY: SUNY Press.

Prayag, G. \& Hosany, S. (2014). When Middle East meets West: Understanding the motives and perceptions of young tourists from United Arab Emirates. Tourism Management, 40, 3545 .

Prideaux, B. (1997). Korean outbound tourism: Australia's response. Journal of Travel \& Tourism Marketing, 7(1), 93-102.

Ren, C., Pritchard, A. \& Morgan, N. (2010). Constructing tourism research: A critical inquiry. Annals of Tourism Research, 37(4), 885-904. 
Richardson, T. (2013). Borders and mobilities: Introduction to the special issue. Mobilities, 8(1), 1-6.

Rogerson, C.M. (2004). Regional tourism in South Africa: A case of 'mass tourism of the South'. GeoJournal, 60, 229-237.

Rogerson, C.M. \& Lisa, Z. (2005). "Sho't left" changing domestic tourism in South Africa. Urban Forum. 16(2-3), 88-111.

Rogerson, C.M. \& Rogerson, J. M. (2011). Tourism research within the Southern African development community: Production and consumption in academic journals, 2000-2010. Tourism Review International, 15(1-2), 213-224.

Said, E. (1978). Orientalism. New York; Random House.

Salazar, N. (2013). Imagining mobility at the "end of the world". History and Anthropology, 24(2), 233-252.

Sammarchi, M. (2001). Situación actual de turismo en Argentina. Cuadernos de Turismo, 8, 129-144.

Sheller, M. \& Urry, J. (2004). Tourism mobilities: places to play, places in play. London: Routledge.

Sheller, M \& Urry, J, (2006). The new mobilities paradigm. Environment and Planning A, 38, 207-226.

Shepherd, R. (2009). Cultural preservation, tourism and 'donkey travel' on China's frontier. In T. Winter, P. Teo \& T.C. Chang eds., Asia on tour: Exploring the rise of Asian tourism (pp. 253-263). London: Routledge.

Schiller, N.G., Basch, L. \& Blanc, C.S. (1995). From immigrant to transmigrant: Theorizing transnational migration. Anthropological Quarterly, 68(1), 48-63.

Singh, Sh. (2009). Domestic tourism in Asia. London: Earthscan.

Shohat, E. \& Stam, R. (1994). Unthinking Eurocentrism: multiculturalism and the media. London: Routledge.

Towner, J. (1995). What is tourism's history? Tourism Management, 16(5), 339-343.

Tribe, J. (2006). The truth about tourism. Annals of Tourism Research, 33(2), 360-381.

Tribe, J., Xiao, H. \& Chambers, D. (2012). The reflexive journal: Inside the black box. Annals of Tourism Research, 39(1), 7-35.

Turner, L. \& Ash, J. (1975). The golden hordes: international tourism and the pleasure periphery. London: Constable.

Uriely, N. (2010). "Home" and "away" in VFR tourism. Annals of Tourism Research 37(3), 854-857. 
Uriely, N. \& Shani, A. (2012). VFR tourism: The host experience. Annals of tourism Research 39, (1), 421-440.

Urry, J. (2000). Sociology beyond societies: Mobilities for the Twenty-first Century. London: Routledge.

Urry, J. (2002). Mobility and proximity. Sociology, 36(2), 255-274.

Urry, J. (2007). Mobilities. Cambridge: Polity Press.

Vaporis, C.N. (1995). The early modern origins of Japanese tourism. Senri Ethnological Studies, 38, 25-38.

Wallerstein, I. (1997). Eurocentrism and its avatars. New Left Review.

Wang, N. (1999). Rethinking authenticity in tourism experience. Annals of tourism Research, 26(2), 349-370.

Williams, A. (2013). Mobilities and sustainable tourism: path-creating or path-dependent relationships? Journal of Sustainable Tourism, 21(4), 511-531.

Wimmer, A. \& Glick Schiller, N. (2003). Methodological nationalism, the social sciences, and the study of migration: An essay in historical epistemology. International Migration Review, 37(3), 576-610.

Winter, T. (2009a). Asian tourism and the retreat of anglo-western centrism in tourism theory. Current Issues in Tourism, 12(1), 21-31.

Winter, T. (2009b). Conclusion: recasting tourism theory towards an Asian future. In T. Winter, T., P. Teo \& T.C. Chang (Eds.), Asia on tour (pp. 315-325). London and New York: Routledge.

Winter, T., Teo, P. \& Chang, T.C. (2009). Asia on Tour. London and New York: Routledge.

Xiao, H. \& Smith, S.L.J. (2006). Towards a paradigm shift of knowledge: Implications for tourism research in China. China Tourism Research, 2(4), 402-422.

Xu, H., Cui, Q., Ballantyne, R. \& Packer, J. (2013). Effective environmental interpretation at Chinese natural attractions: The need for an aesthetic approach. Journal of Sustainable Tourism, 21(1), 117-133.

Yang, J., Ryan, C. \& Zhang, L. (2012). The use of questionnaires in Chinese tourism research. Annals of Tourism Research, 39(3), 1690-1693. 